\title{
An Evaluation of the Garbage Impact on Coastal Environment Conservation at Kora-Kora Tourism Kapataran Village, Lembean Timur District
}

\author{
Denny Maliangkay *, Joy Kumaat, Trenny Tewal \\ Geography Study Program, Faculty of Social Sciences, Manado State University, North Sulawesi
}

\begin{abstract}
This study aims to describe how the impact of waste on tourism visits, and public health around the Kora-kora coast. Get an idea of why tourist visits on the Kora-kora coast have decreased dramatically and explain how to preserve the coast for the development of marine tourism. To enlighten the public on how to properly dispose of waste in order to maintain environmental health around the Kora-kora coast. The method used is descriptive qualitative and provides up-to-date information so that it is useful for the development of science and can be applied more to various problems From the results of the discussion, several conclusions were obtained as follows; There are several factors that cause people to throw garbage on the coast of Kora-kora Kapataran village, among others; There is no designated place for garbage disposal or landfill around Kora-kora beach; People are reluctant to transport garbage to a place that is a bit far from settlements; Garbage transportation facilities do not exist; Do not have a garbage collection location. People often throw garbage on the beach as a shortcut. Lack of socialization and government support regarding waste management and processing.
\end{abstract}

Keywords: Garbage impact, Environmental Conservation, Tourism Village

\section{Introduction}

Indonesia is an archipelagic country, although it is separated by a sea of people consisting of various tribes, it can be united with the motto Bhineka Tunggal Ika. The livelihoods of the community are not only as farmers but also as fishermen. There are many beach attractions on the island of Sulawesi, including the Kora-Kora beach. Kora-kora coastal tourism in Kapataran village needs serious attention from the government, because it is a tourist attraction visited by many local and foreign tourists. Now the coast of Kora is starting to be polluted with various garbage that is thrown carelessly by the community. If this waste cannot be controlled/resolved, the coastal environment will be polluted and as a result coral and mangrove structures will be damaged, which implies that the beach becomes less attractive and visits to this tourist attraction will decrease.

Garbage is a national problem, because in big cities up to the village the garbage disposal is carried out carelessly by the community, even though it has been scheduled at a certain time the garbage disposal hours have been regulated, for example in the city of Manado the garbage disposal hours start at 18.00 to 06.00 . Indiscriminate disposal of garbage is very dangerous for the health of the environment, can cause unpleasant odors and is a source of various diseases.

Coastal areas and beaches that are tourist attractions, if garbage is scattered, it will reduce the interest of tourists to visit, so that the country's foreign exchange is reduced. Another impact is environmental damage which causes disruption of the ecosystem for laying eggs and breeding of animals, including fish.

Public awareness in environmental conservation is absolutely necessary. Especially in coastal areas which are very complex areas, and also most of them are still underdeveloped areas. Public awareness about environmental conservation is still low, reflected in daily activities such as littering, the assumption that burning garbage is the most practical and fast way to dispose of waste, logging and destroying mangrove forests without replanting, building housing and offices without taking into account water absorption. into the ground, etc. To increase public awareness of environmental conservation, among others, community empowerment programs can be carried out through awareness training and intensive assistance to the community and directly involving the community in planning, implementing and maintaining regional management.

\footnotetext{
* Corresponding author : dennymaliangkay@unima.ac.id
} 
Disposal of mixed waste can damage and reduce value and materials that may still be used again. Not all materials in the waste are useless, even most of the waste materials can be converted into useful materials such as used cans which can be used as raw materials for the children's toy industry, used plastic materials, buckets, jerry cans, packaging. , aqua bottles and others can be recycled into the original materials or converted into other forms, as well as metal materials. Wet waste from household waste and natural waste such as leaves and other rotting and decaying plant remains can be processed into compost. (Nur Hidayanti, 2002).

The Kora-kora beach located in the village of Kapataran, Lembean Timur District, Minahasa Regency is currently experiencing a decline in aesthetic beauty and environmental damage has occurred, making it difficult to use it again for the benefit of humans. Several years ago this blood was visited by many tourists, both local (domestic) and international tourists. The sea water and the coast is a beautiful and enchanting sight, clean, good for bathing and fishing and others that are potential to be visited by tourists. Currently the conditions on the coast of Kora-Kora are not attractive anymore, because environmental damage and pollution have occurred. Pollution that occurs is caused by the wrong behavior of the surrounding community. The surrounding community still uses the surrounding area to extract natural resources without paying attention to and taking into account environmental sustainability.

Garbage around the coast of Kora kora, Kapataran Village, has disturbed the landscape, people have assumed that littering is a normal thing. People's behavior like this that does not think about the impact needs to get guidance from the government.

\section{Research Method}

This research aims to Describe how the impact of waste on tourism visits, and public health around the Korakora coast. Get an idea of why tourist visits on the Korakora coast have decreased dramatically and. explain how to preserve the coast for the development of marine tourism and o enlighten the public on how to properly dispose of waste in order to maintain the health of the environment around the Kora-kora coast. A quantitative descriptive was used and adopts one variable, namely to determine the community's response to waste management based on $3 \mathrm{R}$ (Reduce, Reuse and Recycle) in the residential area of Kora-kora beach.

\section{Result And Discussion}

\subsection{A. Description of Research Area}

The research was carried out on the coast of Kora-kora, Kapataran village, Miahasa Regency. Data was collected by direct observation with a sample of 50 as respondents.

Based on the results of the study, the distribution of respondents according to age can be seen in the table below:
Tabel 1. Distribution of Respondents by Age on the Kora-kora Coast

\begin{tabular}{|c|c|c|c|}
\hline No & $\begin{array}{c}\text { Age } \\
\text { (Years) }\end{array}$ & F & \% \\
\hline 1 & $20-25$ & 7 & 13 \\
\hline 2 & $26-36$ & 13 & 21.82 \\
\hline 3 & $37-46$ & 20 & 36.18 \\
\hline 4 & $47-56$ & 15 & 29 \\
\hline \multicolumn{2}{|r|}{ Total } & 55 & 100.00 \\
\hline
\end{tabular}

Table 1 , shows that the age of 20-25 years are 6 people $(10.91 \%), 26-36$ years are 12 people $(21.82 \%)$, $37-46$ years are 21 people $(38.18 \%)$, and $47-56$ years as many as 16 peoples $(29.09 \%)$.

Table 2. Distribution of Respondents by Education on the Kora-kora Coast

\begin{tabular}{|c|l|c|c|}
\hline No & Education & F & \% \\
\hline 1 & $\begin{array}{l}\text { Not finish } \\
\text { elementary } \\
\text { school }\end{array}$ & 6 & 12.73 \\
\hline 2 & $\begin{array}{l}\text { Elementary } \\
\text { school }\end{array}$ & 13 & 21.82 \\
\hline 3 & $\begin{array}{l}\text { Junior High } \\
\text { School }\end{array}$ & 13 & 21.82 \\
\hline 4 & $\begin{array}{l}\text { Senior High } \\
\text { School }\end{array}$ & 21 & 37.82 \\
\hline 5 & Collage & 3 & 7.28 \\
\hline \multicolumn{2}{|l|}{ Total } & 53 & 100.00 \\
\hline
\end{tabular}

Based on the data above, it is known that respondents with education level did not finish elementary school (12.73\%), finished elementary school (21.82\%), graduated from junior high school (21.82\%), graduated from high school $(37.82 \%)$ and the distribution of educational characteristics of the lowest respondents was higher education (7.28\%).

\subsection{Factors That Cause People to Dispose of Garbage}

The need for a final waste disposal site (TPA) is now a major need. Currently, some of the last landfill sites are carried out somewhere by littering, without making any processing. Once the location is full, the place is abandoned and looks for a new location. People tend to use the beach to dispose of garbage. Open dumping of garbage on the beach causes unpleasant odors, attracts flies, spreads bacteria and causes germs of other diseases.

The results of field observations show that most of the waste disposed of on the beach is organic and nonorganic waste. Organic waste is wet waste left over from domestic activities that is easily decomposed, while non-organic is one that is not easy to decompose. Based on the data obtained, there are several types of waste that are often disposed of by respondents on the beach as shown in the following table : 
Table 3. Types of Garbage that are often disposed of on the Coastal Coast of Kora-Kora

\begin{tabular}{|c|l|c|c|}
\hline No & \multicolumn{1}{|c|}{$\begin{array}{c}\text { Types of Garbage Thrown } \\
\text { on the Kora-kora Beach }\end{array}$} & F & $\%$ \\
\hline 1 & Vegetables, Leftovers, fruits & 7 & 14.55 \\
\hline 2 & Plastic, bottles, beverage cans & 14 & 30.91 \\
\hline & $\begin{array}{l}\text { Mixtures (vegetables, } \\
\text { leftovers, cardboard, fruit, } \\
\text { plastic, bottles, used cans, } \\
\text { etc. }\end{array}$ & 23 & 54.55 \\
\hline & Total & 45 & 100.00 \\
\hline
\end{tabular}

Based on the data above, it can be explained that 7 respondents or $14.55 \%$ only dispose of organic or recyclable waste such as vegetables, food waste, cardboard and paper. While 14 respondents (30.91\%) often dispose of inorganic waste such as plastic, plastic bottles, used cans and others. Furthermore, most of the respondents, namely 23 respondents $(54.55 \%)$ often dispose of organic and inorganic waste.

Based on these conditions, it can be stated that waste is not an easy matter. Not only densely populated urban areas, rural areas, or other locations can not be separated from this problem. The source of the waste problem is always present in the community.

Based on existing data, it can be stated that there are several factors that cause people to throw garbage on the beach.

1) There is no special place for garbage disposal or landfill around the Kora-kora beach;

2) Waste transportation facilities are limited and unable to transport all waste;

3) There is no waste processing technology that is not optimal so that it is slow to decompose;

4) Not all neighborhoods have garbage collection locations;

5) People often throw garbage on the beach as a shortcut;

6) Lack of socialization from the government regarding waste management and processing and its products;

7) Waste management is not effective. This can lead to misunderstandings, especially for the surrounding community who live on the kora-kora beach.

The above factors must be addressed immediately which will harm humans. The community and local government need to overcome them, to restore the tourism potential of the coast and the coast of Kora-kora. Based on the data obtained, it shows that the main causes of people's behavior in littering are :

a. The community's belief system towards the behavior of disposing of garbage on the beach of Kora-kora, Kapataran village, considers disposing of garbage as not a problem, this is due to the lack of government socialization in terms of indiscriminate garbage disposal. So that people feel that the behavior of littering is not a wrong thing.

b. Legal awareness about the cleanliness of the coastal environment by the community is still very minimal. This behavior of littering will certainly never be separated from the influence of the surrounding environment. Currently, in responding to the problem of littering, it has become a behavior pattern in society that is "ordinary" or legal because everyone does it. Unconsciously, the behavior of littering will become a form of behavior that is internalized in the mind that littering is not wrong. Someone will perform an action that is considered easier to do because of the availability of resources. So, people will not litter if there are lots of trash cans on the side of the road.

c. A dirty place and indeed a lot of garbage, a place that was originally filled with a lot of garbage, can make people believe that littering is allowed in that place. So the local residents do not hesitate to dispose of their garbage.

d. Not many trash cans. This makes it difficult for people to dispose of their garbage.

The most disturbing thing when the writer interviewed several people, did you know that littering is not allowed? and the answers they all answered know. The problem now is that we know that it shouldn't be done but why do we always do it and this is a question to the author and why he already knows but does it, maybe because he sees the situation where there is no sanction if it violates and the lack of counseling from the government or NGOs who care about waste and environmental hygiene.

Therefore, the participation of the community in waste management is the willingness of the community to help the success of the waste management development program according to each person's ability without sacrificing their own interests. Without community participation, all planned solid waste management programs will be in vain.

\subsection{Impact of Garbage on Coastal Tourism Kora-kora}

Garbage is a by-product of daily human activities. The increasing amount of waste requires management that must be carried out responsibly. During the waste handling stage, there are many activities and facilities that if not carried out/provided properly will have an impact that has the potential to disrupt the environment. The following are some of the impacts caused by garbage disposal on Kora-kora beach ;

1. This openly covered land will give a very bad impression of the view that will affect the aesthetics of the surrounding environment.

2. Many people in Kapataran especially those who live around the coast of Kora-kora in which also do not feel happy with the disposal of garbage on the 
beach. Many people are also against/opposition of other communities who often throw garbage on the beach. This opposition will rationally continue to increase as their education and standard of living increases, so it is very important to consider this impact and take active steps to avoid it.

3. Another negative impact is littering indiscriminately and not properly controlled, making it a suitable place for several organisms and attracting various animals such as flies that gather and can cause disease. According to some respondents that several types of diseases such as diarrhea, cholera, typhus spread quickly because of viruses that come from garbage on the beach.

4. Impact on Socio-Economic - Poor waste management can create an unpleasant environment for the community, unpleasant odors and bad views on the beach because garbage is scattered everywhere, on the coast causing the coast of Korakora to be unattractive. to be visited resulted in a decrease in people's income.

Waste management in Indonesia, especially in a district/city, recognizes 3 (three) management groups, namely :

1. Management by non-governmental organizations: waste management from the source to the collection point, or to other processing sites. In cities, this management is usually carried out by the RT/RW, with activities to collect waste from garbage bins at waste sources, for example at homes, transported by means prepared by the community themselves, to temporary shelters.

2. Formal management: usually carried out by the Regency/City Government, or other institutions including the private sector appointed by the Regency/City. The first stage of waste disposal is carried out by the waste producer. In residential areas, this activity is usually carried out by the $\mathrm{RT} / \mathrm{RW}$, where waste is transported from the trash bin to the TPS. The next stage, waste from the TPS is transported to the TPA by a garbage truck belonging to the city manager or a designated institution. Usually, a city's budget has not been able to handle all the waste produced.

3. Informal Management: formed due to the encouragement of the need to live from some people, who unconsciously have participated in the handling of municipal waste. This informal system views waste as an economic resource through collecting, sorting, and selling waste for recycling. This series of activities involves scavengers, scavengers, stalls, dealers, and the recycling industry in a series of trading systems.

\section{Conclusion}

The results of the discussion above, some conclusions are obtained as follows:

1. There are several factors that cause people to throw garbage on the coast of Kora-kora Kapataran village, among others

2. There is no place specifically provided for garbage disposal or landfill around Kora-kora beach;

3. People are reluctant to transport garbage to a place that is a bit far from settlements;

4. Garbage transportation facilities do not exist

5. Does not have a garbage collection location. People often throw garbage on the beach as a shortcut,

6. Lack of socialization and government support regarding waste management and processing and its products,

7. Ineffective or almost non-existent waste management can cause misunderstandings, especially for the surrounding community who live on the Kora-kora coast.

The impact of carelessly throwing garbage, among others

a. Impact on Health.

b. Diarrhea, cholera, typhus spread rapidly due to viruses originating from garbage with improper management because they are close to recreation. Dengue fever can also increase rapidly in areas where waste management is inadequate. - Fungal diseases can also spread (eg skin fungus)

c. Impact on Socio-Economic, because the aesthetic value of the beach decreases as a result, the interest of tourists decreases to visit Kora beach

\section{References}

[1] Anonim. 2001. Direktorat Jenderal Pesisir Pulau Kecil. Naskah Akademik

[2] Anonim. 2018 Pengelolaan dan Pulau Wilayah Pesisir. Departemen Kelautan dan Perikanan. Jakarta

[3] Apriadji W.H., 2012. Memproses Sampah. Penabur Swadaya. Jakarta.

[4] Gumbira S., 2007. Sampah Masalah Kita Bersama. Medaitma Perkasa. Jakarta.

[5] Poedjawijatama., 1998. Manusia dan Alamnya. Bina Aksara. Jakarta

[6] Soerjani Moh. dkk., 1988. Lingkungan: Sumber Daya Alam dan Kependudukan Dalam Pengembangan. UI Press. Jakarta.

[7] Soewedo., 1993. Jalan Sampah. http://wwwjala/sampah.Or.Id/.

[8] Winarno Surakhmad, 1982. Penelitian Ilmiah Dasar Metode Teknik. Tarsito. Bandung. 